\title{
Current US Food and Drug Administration-Approved Pharmacologic Therapies for the Treatment of Irritable Bowel Syndrome with Diarrhea
}

\author{
Darren M. Brenner • Gregory S. Sayuk
}

Received: August 21, 2019 / Published online: November 9, 2019

(C) The Author(s) 2019

\section{ABSTRACT}

Irritable bowel syndrome (IBS) is a functional bowel disorder characterized by abdominal pain and alterations in stool form and/or frequency, leading to reduced quality of life. Pharmacologic agents currently approved by the US Food and Drug Administration for treatment of IBS with diarrhea (IBS-D) in adults are the nonsystemic antibiotic rifaximin, the mixed $\mu$ - and $\kappa$ opioid receptor agonist/ $\delta$-opioid antagonist eluxadoline, and the selective serotonin $5-\mathrm{HT}_{3}$ antagonist alosetron (the last of which is indicated only in women with severe IBS-D

Enhanced Digital Features To view enhanced digital features for this article go to https://doi.org/10.6084/ m9.figshare.9944903.

D. M. Brenner $(\bowtie)$

Feinberg School of Medicine, Northwestern

University, Chicago, IL, USA

e-mail: darren-brenner@northwestern.edu

G. S. Sayuk

Washington University School of Medicine, Saint

Louis, MO, USA

G. S. Sayuk

St Louis Veterans Affairs Medical Center, Saint

Louis, MO, USA refractory to conventional therapy). Both eluxadoline and alosetron are administered as chronic daily therapies; rifaximin is given as a 2-week course of treatment with repeat courses administered as needed for symptom recurrence. Presumed mechanisms of action of rifaximin include modulation of the gut microbiota, anti-inflammatory activity, normalization of visceral hypersensitivity, and reduction in intestinal permeability. Eluxadoline targets opioid receptors in the gastrointestinal (GI) tract, resulting in decreased GI motility, fluid secretion, and visceral pain perception. Alosetron antagonizes serotonergic afferent neural signals and also slows GI motility. The efficacy and safety of these agents have been investigated in several rigorous clinical trials, and it has been demonstrated that they improve global and individual IBS symptoms. This review highlights the pivotal efficacy and safety data of the three pharmacologic agents currently indicated in the USA for the management of IBS-D in adults.

Funding: Salix Pharmaceuticals.

Keywords: Alosetron; Diarrhea; Eluxadoline; Irritable bowel syndrome; Rifaximin 


\section{Key Summary Points}

Irritable bowel syndrome (IBS) is a common disorder associated with abdominal pain and changes in bowel habits (e.g., diarrhea).

IBS negatively impacts health-related quality of life and can be a substantial physiologic and social burden on patients with the disorder.

Rifaximin, eluxadoline, and alosetron are indicated for the treatment of IBS with diarrhea (IBS-D), and their efficacy in treating the totality of IBS-D symptoms has been shown in several well-designed trials.

Frequency of administration (e.g., shortcourse versus daily therapy) and safety profiles of agents indicated for IBS-D differ and should be taken into consideration when determining a treatment approach.

\section{INTRODUCTION}

Irritable bowel syndrome (IBS) is a functional bowel disorder characterized by recurrent abdominal pain associated with alterations in visceral pain perception, with defecation and/or changes in stool frequency and/or stool form [1]. IBS is a heterogenous condition and is further subclassified by its predominant stool texture [1]. By definition, individuals who have IBS with diarrhea (IBS-D) experience the passage of Bristol Stool Form Scale (BSFS) type 6 or 7 stools (loose, mushy, watery) during more than 25\% of bowel movements, and types 1 and 2 stools (hard, lumpy, pellet-like) less than $25 \%$ of the time. Current Rome IV diagnostic criteria specify that stool texture should be assessed on days with abdominal pain to enable greater precision in differentiating the IBS subtype [1, 2].

IBS is a common disorder, with worldwide prevalence estimates between $8.8 \%$ [3] and
$11.2 \%$ [4]. In the USA, up to $14.1 \%$ of individuals are thought to be affected [5]. Women are almost twice as likely as men to suffer from IBS (14\% vs. $8.9 \%)$, and the prevalence of IBS-D, at up to $40 \%$ of adults, is highest among the IBS subtypes [4]. Although not required for a diagnosis, patients with IBS-D report additional symptoms, including abdominal distention, bloating, increased defecatory urgency, and sensations of incomplete evacuation [1]. IBS-D negatively impacts health-related quality of life, with patients reporting avoidance of planned activities, eating prior to or during social events, and increased absenteeism (missed work or school) and presenteeism (decreased productivity at work or school) in reaction to or for management of their symptoms [6, 7]. Consequently, effective therapies are needed to reduce the substantial physiologic and social burdens of this disorder. In recent years, there has been a shift in the management paradigm from treating isolated symptoms to improving the global symptom profile. The goal of this narrative review is to highlight global efficacy and safety data for current pharmacologic agents approved by the US Food and Drug Administration (FDA) in the USA for IBS-D.

\section{METHODS}

A search of the Medline database for all Englishlanguage articles published through 31 December 2018 (i.e., no start date used in literature search) was conducted to identify relevant articles using the following keywords: "alosetron", "efficacy", "eluxadoline", "irritable bowel syndrome", "irritable bowel syndrome with diarrhea", "IBS-D", "rifaximin", and "safety". Abstracts that discussed pharmacologic agents approved by the FDA for IBS-D were reviewed for safety and/or efficacy data in individuals with IBS-D. Additional relevant publications were identified from article reference lists. This review article is based on studies previously conducted in humans and references two clinical studies performed by the authors. 


\section{FDA-APPROVED THERAPIES FOR IBS-D}

The three pharmacologic agents currently indicated in the USA for treatment of IBS-D in adults have been rigorously analyzed in multiple clinical trials, using standardized trial designs and endpoints from the FDA to examine their efficacy for treating the global symptom profile of IBS. In contrast, loperamide, an over-the-counter therapy for diarrhea, has limited clinical trial data available in IBS, and data supporting its use for overall symptom improvement is lacking. Consequently, the American College of Gastroenterology Monograph authors recently recommended against using it to treat IBS-D [8], but direct comparisons between the FDA-approved agents and loperamide cannot be made, as no head-to-head clinical trials have been published.

Therapies approved for treatment of adults with IBS-D include the nonsystemic antibiotic rifaximin, the mixed $\mu$ - and $\kappa$-opioid receptor agonist/ $\delta$-opioid antagonist eluxadoline, and the selective serotonin $5-\mathrm{HT}_{3}$ antagonist alosetron (only for women with severe IBS-D who have not responded adequately to conventional therapy) [9-11]. The mechanisms of action of rifaximin are believed to include modulation of the gut microbiota, anti-inflammatory activities, and reductions in intestinal permeability, ultimately improving stool texture and reducing pain [12-16]. Eluxadoline targets opioid receptors in the gastrointestinal (GI) tract, reducing visceral pain and decreasing fluid secretion and GI motility [17, 18]. Alosetron antagonizes serotonergic afferent neural signals and also slows GI motility through selective serotonin inhibition, ultimately leading to improvements in pain and diarrhea [19].

\section{Rifaximin}

Rifaximin, an antibiotic that is not absorbed systemically, is administered as a short course of therapy $[550 \mathrm{mg}$ three times daily (t.i.d.) for 2 weeks]. The seminal data supporting its efficacy for treating IBS-D comes from two randomized, double-blind, placebo-controlled phase 3 studies (TARGET 1 and 2) and a unique phase 3 retreatment trial (TARGET 3; Table 1) $[20,21]$. In TARGET 1 and 2, 1258 individuals with non-constipation IBS received $550 \mathrm{mg}$ of rifaximin t.i.d. for 2 weeks, with a significantly greater percentage of rifaximin-treated patients experiencing adequate relief of their global IBS symptoms (primary efficacy endpoint) for at least two of the first 4 weeks post-treatment compared with placebo $[40.7 \%$ vs. $31.7 \%$, respectively (pooled); $P<0.001]$ [20]. The 2-week course of rifaximin also provided significant improvement in bloating versus placebo $[40.2 \%$ vs. $30.3 \%$, respectively (pooled); $P<0.001$ ] [20]. Relief of global IBS symptoms and bloating was maintained for at least 12 weeks in a significantly greater percentage of individuals treated with rifaximin compared with placebo (pooled for each endpoint; $P$ $\leq 0.001$ ), supporting durability of response [20].

The safety profile of rifaximin was comparable to that of placebo in TARGET 1 and 2 [20]. The most commonly reported adverse events (AEs) were headache $(6.1 \%$ vs. $6.6 \%$, respectively), upper respiratory tract infection $(5.6 \%$ vs. $6.2 \%)$, and abdominal pain ( $4.6 \%$ vs. $5.5 \%)$ [20]. Serious AEs were reported in $1.6 \%$ of patients in the rifaximin group and $2.4 \%$ of patients in the placebo group, and there were no documented cases of Clostridium difficile or ischemic colitis [20]. A 2014 pooled safety analysis including the aforementioned data, as well as data from a phase 2 trial, did not find increased risk of infection or substantial differences in $\mathrm{AE}$ rates versus placebo; this adds further credence to the overall safety profile of rifaximin [22].

In the phase 3 IBS-D retreatment study (TARGET 3), all enrollees initially received an open-label course of rifaximin $550 \mathrm{mg}$ t.i.d. for 2 weeks, allowing for a "real-world" assessment of therapeutic effectiveness [21]. A total of 1074 of 2438 participants $(44.1 \%)$ were considered symptom responders (defined as simultaneously achieving at least 30\% decrease from baseline in mean weekly abdominal pain score and at least $50 \%$ decrease from baseline in the number of days/week with BSFS type 6 or 7 stool for at least two of the first 4 weeks post-treatment) and were then monitored during an 18-week 


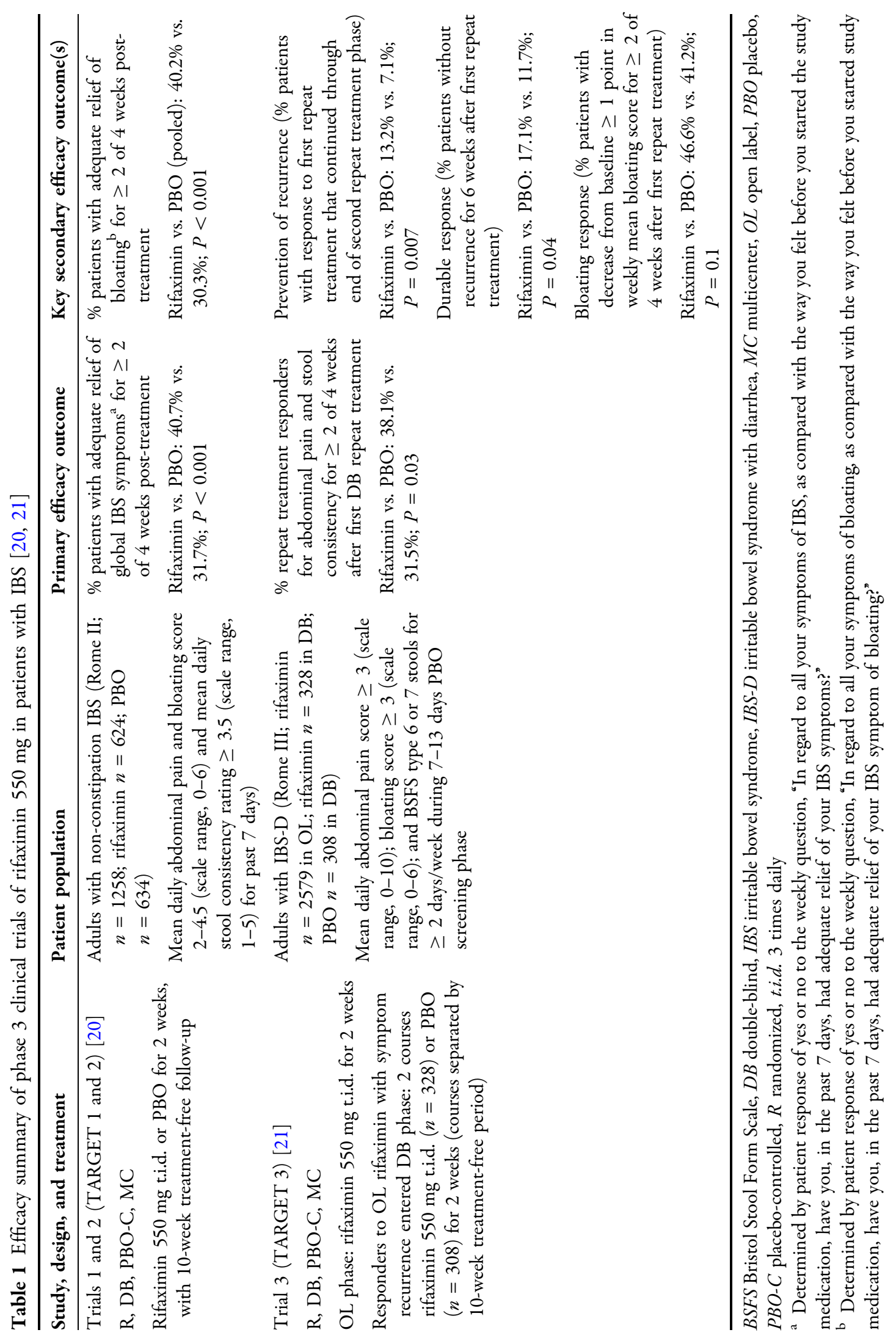


treatment-free phase for assessment of IBS symptom recurrence (loss of abdominal pain or stool consistency response, using the above criteria, for at least 3 weeks in a consecutive, rolling 4-week period) [21]. Patients experiencing symptom recurrence subsequently were randomized in a double-blind manner to receive two 2-week courses of rifaximin $(n=328)$ or placebo $(n=308)$, with each course separated by 10 weeks [21]. A significantly larger percentage of patients in the rifaximin group were responders to repeat treatment (primary efficacy endpoint; assessed using the same abdominal pain and stool consistency composite endpoint) versus placebo (38.1\% vs. $31.5 \%$, respectively; $P=0.03$ ), and prevention of recurrence and durable response were significantly greater with rifaximin versus placebo [21] (Table 1). As observed in the pivotal trials [20], the rifaximin safety profile during the doubleblind phase of TARGET 3 was generally comparable with that of placebo [21]. The most common AEs in the rifaximin and placebo groups during the 22-week double-blind phase were nausea (3.7\% vs. $2.3 \%$, respectively), upper respiratory tract infection $(3.7 \%$ vs. $2.6 \%)$, and urinary tract infection ( $3.4 \%$ vs. $4.9 \%)$. A similar percentage of patients receiving rifaximin $(1.2 \%)$ and placebo (1.3\%) experienced serious AEs, none of which were considered by investigators to be treatment-related.

Because rifaximin is an antibiotic indicated for two retreatments as needed, after the initial course, some have raised theoretical concerns regarding the risk for development of $C$. difficile infection and induction of bacterial antibiotic resistance. However, no cases of $C$. difficile were reported in TARGET 1 and 2 [20]. In TARGET 3, a single case of $C$. difficile infection was identified 37 days after the completion of a repeat rifaximin treatment; it developed immediately following a course of cefdinir for a urinary tract infection [21]. Furthermore, in a substudy of the TARGET 3 population, 1429 bacterial and yeast isolates were identified in stool samples obtained from substudy participants [23]. Minimum inhibitory concentration analyses revealed no clinically meaningful evidence of bacterial antibiotic resistance to rifaximin or rifampin, or cross-resistance between rifaximin and other antibiotics [23].

Though primary outcomes differ across studies, numbers needed to treat (NNT) or harm (NNH) can be calculated to help gauge the potential benefits and risks of IBS-D therapies [24]. For rifaximin, an analysis of six trials $(n=2441)$ determined an NNT of 10.5 [95\% confidence interval (CI) 8-16] [8]. Another analysis, of five rifaximin studies $(n=1187$ treated patients), yielded a similar conclusion (NNT of 10.6) [24]. Importantly, these five studies yielded an NNH of 8971 (based on discontinuation due to an $\mathrm{AE}$ ). This indicates that 846 patients will benefit from rifaximin before one $\mathrm{AE}$ occurs and leads to treatment discontinuation [24].

\section{Eluxadoline}

Eluxadoline, a mixed $\mu$ - and $\kappa$-opioid receptor agonist/ $\delta$-opioid antagonist, is indicated as daily therapy for the treatment of IBS-D [10]. While a dose of $100 \mathrm{mg}$ eluxadoline twice daily (b.i.d.) is recommended for most individuals, a dose adjustment to $75 \mathrm{mg}$ b.i.d. is necessary for those taking concomitant medications that inhibit hepatic organic anion transporting polypeptide 1B1 (OATP1B1) function, or those who have Child-Pugh class A or B hepatic impairment [10]. Eluxadoline $75 \mathrm{mg}$ b.i.d. is also an option for patients who have developed constipation with the $100 \mathrm{mg}$ b.i.d. dosing of the drug [10].

Two phase 3 randomized, double-blind placebo-controlled trials (3001 and 3002) enrolling 2425 patients $(n=1280$ in the 3001 trial and $n=1145$ in the 3002 trial) reported significantly greater rates of combined response in patients treated with $75 \mathrm{mg} \quad(P<0.001)$ or $100 \mathrm{mg}$ $(P<0.001)$ of eluxadoline b.i.d. for up to 26 weeks of therapy compared with placebo (pooled; Table 2) [25]. This combined endpoint response to eluxadoline occurred rapidly, within the first month (weeks 1-4) of therapy [75 mg, $22.8 \%$; $100 \mathrm{mg}, 24.6 \%$; vs. placebo (pooled), $12.5 \% ; P<0.001$ for each dose vs. placebo] [26]. Furthermore, these results were based on the primary endpoint for IBS studies that was 


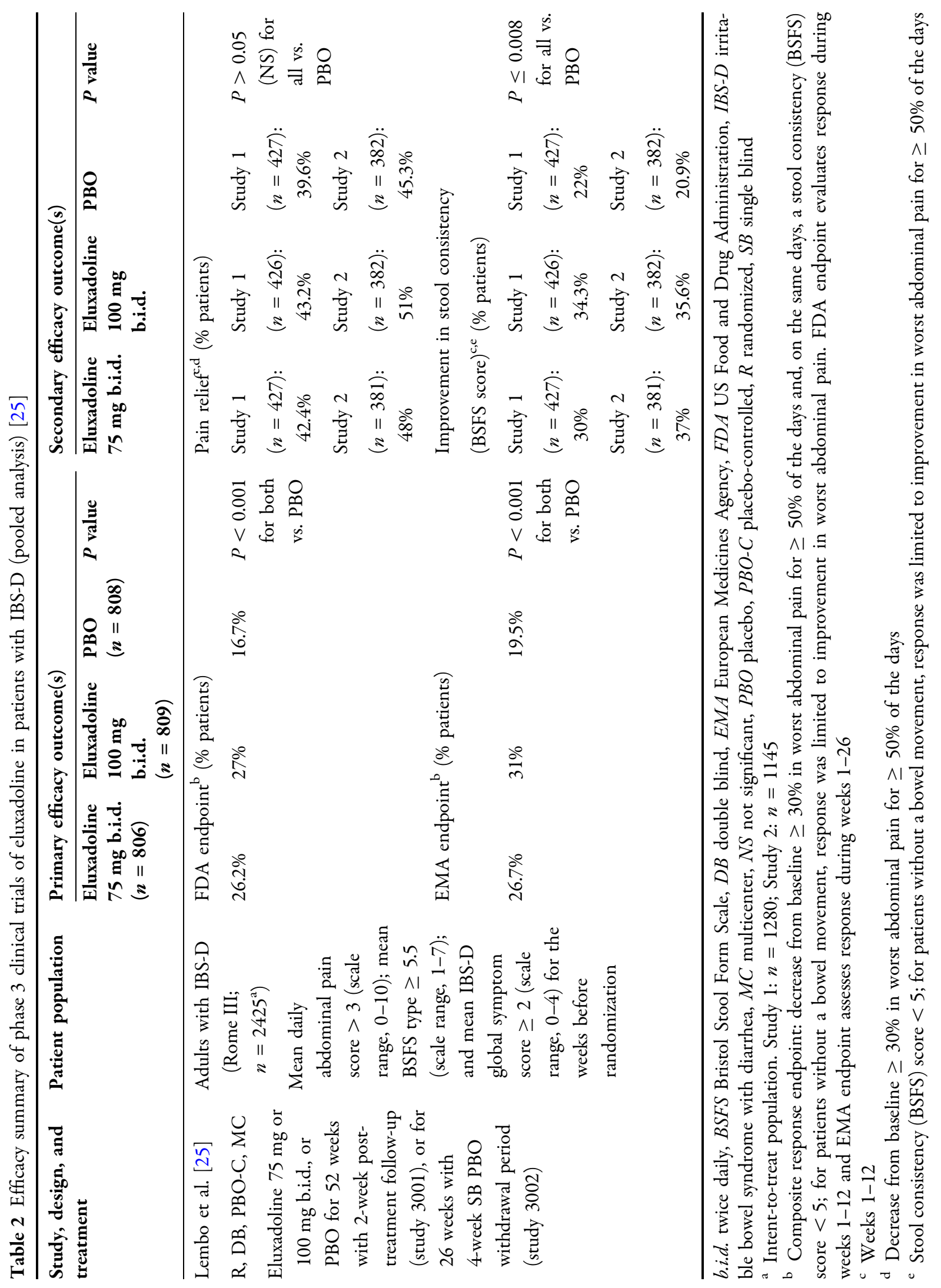


detailed in the most recent FDA guidance (at least $30 \%$ reduction in worst abdominal pain compared with baseline, plus a BSFS score less than 5 (or no bowel movement), on at least $50 \%$ of treatment days) [27]. Both doses of eluxadoline had significantly greater efficacy for improving individual and global symptoms from baseline, compared with placebo at week 12 [stool consistency: $P<0.001$ for both doses vs. placebo; stool frequency: $P=0.002$ (75 mg) and $P<0.001$ (100 mg) vs. placebo; global symptoms: $P=0.008 \quad(75 \mathrm{mg})$ and $P<0.001$ (100 mg)] [25]. Improvements in abdominal pain and bloating from baseline were observed with both doses of eluxadoline, but only the 100-mg dose achieved significance versus placebo (abdominal pain, $P<0.001$; bloating, $P=0.003$ ) [25].

The most common AEs reported for eluxadoline $75 \mathrm{mg}, 100 \mathrm{mg}$, and placebo were constipation $(7.4 \%$ vs. $8.6 \%$ vs. $2.5 \%$, respectively), nausea $(8.1 \%$ vs. $7.5 \%$ vs. $5.1 \%)$, and abdominal pain $(5.8 \%$ vs. $7.2 \%$ vs. $4.1 \%)$; and serious AEs were experienced by $4.2 \%$ versus $4.8 \%$ versus $3.0 \%$ of patients, respectively [25]. Pancreatitis [5/1666 (0.3\%)] and sphincter of Oddi spasm [8/ $1666(0.5 \%)]$ occurred in patients receiving eluxadoline; in nine patients, including all eight individuals experiencing sphincter of Oddi dysfunction spasm, these AEs were associated with the absence of a gallbladder. Another pooled analysis including the two phase 3 studies (3001 and 3002) and a phase 2 study indicated that AEs leading to study discontinuation occurred in a greater percentage of patients receiving eluxadoline $75 \mathrm{mg}$ or $100 \mathrm{mg}$ b.i.d. compared with placebo $(8.3 \%$ of 807 patients and $7.8 \%$ of 1032 patients vs. $4.3 \%$ of 975 patients, respectively) [28]. In this pooled safety analysis, a total of seven serious AEs of pancreatitis were reported during clinical trials [28]. On the basis of data from the three aforementioned trials $(n=3235)$, eluxadoline had an NNT of 12.5 (95\% CI 8-33) [8], and on the basis of discontinuations due to AEs in the phase 3 trials, eluxadoline $75 \mathrm{mg}$ b.i.d. had an NNH of 25.2, while eluxadoline $100 \mathrm{mg}$ b.i.d. had an NNH of 23.3 [25].

Further, data suggests benefits for eluxadoline in specific subpopulations. A post hoc analysis of the phase 3 studies assessed maintenance of response over time and indicated that global responders (abdominal pain and stool consistency) to eluxadoline during the first 4 weeks of treatment were more likely than nonresponders to maintain response with continued treatment during weeks 1 through 12 and 26 (comparisons with placebo; $P$ values not reported) [26]. This suggests that patients not responding within a month of b.i.d. eluxadoline are unlikely to respond with continued daily therapy, thus limiting the overall time needed to assess eluxadoline's potential efficacy [26].

Another post hoc analysis from the two phase 3 trials evaluated a subpopulation of patients who had previously used loperamide and subjectively experienced an inadequate response to this antidiarrheal [29]. In this subpopulation, a higher percentage of individuals receiving eluxadoline experienced significantly greater improvements in their symptoms compared with placebo (eluxadoline $75 \mathrm{mg}$ and $100 \mathrm{mg}$ b.i.d. for 12 weeks vs. placebo; $26.3 \%$ of 198 patients and $27 \%$ of 174 patients, respectively, vs. $12.7 \%$ of 166 patients; $P \leq 0.001$ for both comparisons) [29].

On the basis of these results, a prospective phase 4, multinational, randomized, doubleblind, placebo-controlled trial (RELIEF) was conducted in patients experiencing inadequate IBS-D symptom control with loperamide use in the previous 12 months [30]. In that study's overall population, more than $40 \%$ of patients discontinued loperamide because of a perceived lack of improvement of abdominal symptoms, and more than $40 \%$ discontinued loperamide specifically because of lack of improvement of bowel symptoms [30]. Primary responders were those meeting criteria defined similarly in the phase 3 trials, except that in the current trial, participants had to experience a more rigorous $40 \%$ or more reduction in their worst abdominal pain compared with baseline, plus a BSFS score less than 5 (or no bowel movement), on at least $50 \%$ of treatment days $[25,30]$. A significantly greater percentage of the 172 patients treated with eluxadoline $100 \mathrm{mg}$ b.i.d. for 12 weeks were combined responders, compared with the 174 patients treated with placebo (22.7\% vs. $10.3 \%$, respectively; $P=0.002)$ [30]. 
In the RELIEF trial, serious AEs of pancreatitis or sphincter of Oddi spasm were not observed in any patients, likely related to careful patient screening and exclusion of post-cholecystectomy patients from the study [30]. Additional postmarketing reports of pancreatitis and sphincter of Oddi dysfunction identified via the Federal Adverse Event Reporting System have been published [31]. In early 2017, the FDA issued a safety announcement about the increased risk of serious pancreatitis in patients without a gallbladder, and eluxadoline is now contraindicated in this population [10].

\section{Alosetron}

As noted previously, alosetron has the most restricted indication of the three agents currently FDA-approved for IBS-D, requiring prescription under an FDA modified Risk Evaluation and Mitigation Strategy (REMS) program [32]. It is currently indicated as b.i.d. treatment for women with chronic (less than 6 months) and severe (defined as at least one of the following: painful stomach cramps or bloating, fecal incontinence, and/or severe impact on quality of life) IBS-D symptoms once biochemical and anatomical abnormalities have been excluded and there has been a lack of response to traditional IBS-D therapies [11]. Multiple studies have evaluated alosetron in patients with IBS, but the studies were conducted prior to FDA guidance on appropriate endpoints for IBS-D trials and/or included individuals with the IBS mixed (IBS-M) subtype (Table 3) [33-38]. Only three trials assessed global symptoms [34-36]. In the first of these studies, published by Lembo et al., 801 women with non-constipated IBS (IBS-D, 98\%) were randomly assigned to receive alosetron $1 \mathrm{mg}$ b.i.d. or placebo for 12 weeks [35]. Global improvement (defined as moderate or substantial improvement in IBS symptoms) was established a priori as a key secondary endpoint [35]. At week $12,76 \%$ of the patients receiving alosetron endorsed experiencing global improvement, compared with $44 \%$ of those receiving placebo $(P<0.001)$ [35]. The second trial, by Krause et al., reported that a significantly greater percentage of women with severe IBS-D $(n=705)$ who received alosetron $0.5 \mathrm{mg}$ or $1 \mathrm{mg}$ once daily or alosetron $1 \mathrm{mg}$ b.i.d. experienced moderate or substantial IBS global improvement versus placebo at week 12 (50.8\% of 177 patients, $48.0 \%$ of 175 patients, and $42.9 \%$ of 177 patients vs. $30.7 \%$ of 176 patients, respectively; $P \leq 0.02$ for all doses vs. placebo) [36]. Finally, in a 2018 openlabel prospective study by Lacy et al. using the current FDA composite endpoint (i.e., improvement from baseline of at least 30\% in abdominal pain and decrease from baseline of at least $50 \%$ in number of days/week with at least one stool with BSFS type 6 or 7 for at least $50 \%$ of treatment weeks), $45 \%$ of 105 evaluable women with severe IBS-D who received open-label alosetron $0.5 \mathrm{mg}$ b.i.d. (with potential for increase to $1 \mathrm{mg}$ b.i.d. after 4 weeks) were considered responders at week 12 [34].

Despite initial data yielding positive results, the drug was voluntarily commercially withdrawn in November 2000 because of postmarketing increases in the rates of complicated constipation (obstruction or perforation), ischemic colitis, and mortality. It was subsequently reintroduced in November 2002 by the FDA under a REMS program for use in the aforementioned restricted patient population. Subsequent data from 9 years of patient follow-up revealed an adjudicated incidence rate of 1.03 cases/1000 patient-years of exposure for ischemic colitis and a rate of 0.25 cases/ 1000 patient-years of exposure for constipation [39]. In January 2016, the FDA further reduced the requirements for prescribing this therapy under the REMS program; since then, prescribers are only required to participate in an informational program and complete related forms [32]. In an analysis of eight trials (4987 patients), the NNT for alosetron was 7.5 (95\% CI 5-16), whereas its NNH was 10 (95\% CI 6-20) [8].

\section{CONCLUSIONS}

Rifaximin, eluxadoline, and alosetron are indicated for the treatment of IBS-D, and their efficacy for treating the totality of IBS-D symptoms has been proven in multiple well-designed trials with similar NNTs. Comparative data for overthe-counter agents are lacking, and where 
Table 3 Efficacy summary of clinical trials of alosetron in patients with IBS-D [33-38]

\begin{tabular}{|c|c|c|c|}
\hline $\begin{array}{l}\text { Study, design, and } \\
\text { treatment }\end{array}$ & Patient population & Primary efficacy outcome & $\begin{array}{l}\text { Key secondary efficacy } \\
\text { outcome(s) }\end{array}$ \\
\hline $\begin{array}{l}\text { Camilleri et al. [33] } \\
\text { R, DB, PBO-C, MC } \\
\text { Alosetron 1, 2, 4, or } \\
8 \text { mg b.i.d. or PBO for } \\
12 \text { weeks, with 2-week } \\
\text { treatment-free follow- } \\
\text { up }\end{array}$ & $\begin{array}{l}\text { Adults with IBS-D or IBS-M } \\
\text { for } 6 \text { months (Rome I; } \\
n=370 ; \text { alosetron: } 1 \mathrm{mg} \\
n=72,2 \mathrm{mg} n=74,4 \mathrm{mg} \\
n=76,8 \mathrm{mg} n=68 ; \mathrm{PBO} \\
n=80) \\
\text { Mean daily abdominal pain } \\
\text { 1.5-3.3 (scale range, } 0-4) ; \\
\text { and mean daily stool } \\
\text { consistency rating } \geq 2.5 \\
\text { (scale range, } 1-5 \text { ) }\end{array}$ & $\begin{array}{l}\% \text { patients with adequate relief } \\
\text { of pain and discomfort } \\
\text { Alosetron ( } 1 \mathrm{mg} \text { and } 2 \mathrm{mg} \text { ) vs. } \\
\text { PBO: } 60 \% \text { and } 59 \% \text { vs. } 33 \% \text {; } \\
P \leq 0.02 \text { for both vs. PBO } \\
\text { (only female responders) }\end{array}$ & $\begin{array}{l}\text { Patients with adequate relief } \\
\text { of bowel movement } \\
\text { urgency, and frequency, } \\
\text { and improved stool } \\
\text { consistency } \\
\text { Alosetron vs. PBO: } P<0.05 \\
\text { (only female responders) }\end{array}$ \\
\hline $\begin{array}{l}\text { Camilleri et al. [38] } \\
\text { R, PBO-C, MC } \\
\text { Alosetron } 1 \mathrm{mg} \text { b.i.d. or } \\
\text { PBO for } 12 \text { weeks, } \\
\text { with 4-week } \\
\text { treatment-free follow- } \\
\text { up }\end{array}$ & $\begin{array}{l}\text { Women with IBS-D or IBS-M } \\
\text { for } \geq 6 \text { months (Rome I; } \\
n=647 ; \text { alosetron } n=324 ; \\
\text { PBO } n=323 \text { ) } \\
\text { Mean daily abdominal pain } \\
\text { 1.0-3.3 (scale range, } 0-4 \text { ); } \\
\text { and mean daily stool } \\
\text { consistency rating } \geq 2.5 \\
\text { (scale range, } 1-5 \text { ) }\end{array}$ & $\begin{array}{l}\% \text { patients with adequate relief } \\
\text { of pain and discomfort for } \\
\geq 2 \text { weeks/month }{ }^{\mathrm{a}} \\
\text { Alosetron ( } 1 \mathrm{mg}) \text { vs. } \mathrm{PBO} \text { : } \\
\text { All } 3 \text { months: } 41 \% \text { vs. } 29 \% \\
\text { Month 1: } 52 \% \text { vs. } 42 \% \text {; } \\
P=0.02 \\
\text { Month } 3: 56 \% \text { vs. } 47 \% \text {; } \\
P=0.02\end{array}$ & $\begin{array}{l}\text { Patients with adequate relief } \\
\text { of bowel movement } \\
\text { urgency, and frequency, } \\
\text { and improved stool } \\
\text { consistency } \\
\text { Alosetron vs. PBO: } P<0.05\end{array}$ \\
\hline $\begin{array}{l}\text { Camilleri et al. [37] } \\
\text { R, DB, PBO-C, MC } \\
\text { Alosetron } 1 \mathrm{mg} \text { b.i.d. or } \\
\text { PBO for } 12 \text { weeks, } \\
\text { with 4-week } \\
\text { treatment-free follow- } \\
\text { up }\end{array}$ & $\begin{array}{l}\text { Women with IBS-D or IBS-M } \\
\text { for } \geq 6 \text { months (Rome I; } \\
n=626 \text {; alosetron } n=309 \text {; } \\
\text { PBO } n=317 \text { ) } \\
\text { Mean daily abdominal pain } \\
1.0-3.3 \text { (scale range, } 0-4 \text { ); } \\
\text { and mean daily stool } \\
\text { consistency rating } \geq 2.5 \\
\text { (scale range, } 1-5 \text { ) }\end{array}$ & $\begin{array}{l}\% \text { patients with adequate relief } \\
\text { of pain and discomfort for } \\
\geq 2 \text { weeks } / \text { month }^{\mathrm{a}} \\
\text { Alosetron } 1 \mathrm{mg} \text { vs. } \mathrm{PBO} \text { : } \\
\text { All } 3 \text { months: } 41 \% \text { vs. } 26 \% \text {; } \\
P<0.0001 \\
\text { Month } 1: 50 \% \text { vs. } 39 \% \text {; } \\
P<0.05 \\
\text { Month } 3: 60 \% \text { vs. } 41 \% \text {; } \\
P<0.001\end{array}$ & $\begin{array}{l}\text { Patients with adequate relief } \\
\text { of bowel movement } \\
\text { urgency, frequency, and } \\
\text { improved stool } \\
\text { consistency } \\
\text { Alosetron vs. PBO: } \\
P<0.001 \\
\text { At week } 12 \text {, alosetron relative } \\
\text { to PBO: } \\
\text { Urgency decreased by } 12.6 \% \\
\text { Stool frequency decreased by } \\
0.5 \text { stools/day } \\
\text { Stool firmness increased by } \\
0.6 \text { points }\end{array}$ \\
\hline
\end{tabular}


Table 3 continued

\begin{tabular}{|c|c|c|c|}
\hline $\begin{array}{l}\text { Study, design, and } \\
\text { treatment }\end{array}$ & Patient population & Primary efficacy outcome & $\begin{array}{l}\text { Key secondary efficacy } \\
\text { outcome(s) }\end{array}$ \\
\hline $\begin{array}{l}\text { Lembo et al. [35] } \\
\text { R, DB, PBO-C, MC } \\
\text { Alosetron } 1 \mathrm{mg} \text { b.i.d. or } \\
\text { PBO for } 12 \text { weeks, } \\
\text { with 2-week } \\
\text { treatment-free follow- } \\
\text { up }\end{array}$ & $\begin{array}{l}\text { Women with recurrence of } \\
\text { non-constipation IBS for } \\
\geq 12 \text { weeks in previous } 12 \\
\text { months (Rome II; } n=801 \text {; } \\
\text { alosetron } n=532 ; \text { PBO } \\
n=269 \text { ) } \\
\text { Abdominal pain/discomfort } \\
\text { associated with } \geq 2 \\
\text { symptoms: relief of symptoms } \\
\text { with defecation, change in } \\
\text { stool frequency and/or } \\
\text { consistency }\end{array}$ & $\begin{array}{l}\% \text { of days patients reported } \\
\text { having satisfactory control of } \\
\text { IBS-related bowel movement } \\
\text { urgency for } 12 \text { weeks } \\
\text { Alosetron } 1 \mathrm{mg} \text { vs. PBO: } \\
0.73 \text { days vs. } 0.57 \text { days; } \\
P<0.001\end{array}$ & $\begin{array}{l}\text { Patients with moderate or } \\
\text { substantial improvement in } \\
\text { global IBS symptoms }{ }^{\mathrm{d}} \text { over } \\
\text { the previous } 4 \text { weeks } \\
\text { Alosetron } 1 \mathrm{mg} \text { vs. } \mathrm{PBO} \text { : } \\
\text { Week } 4: 67 \% \text { vs. } 41 \% \text {; } \\
P<0.001 \\
\text { Week } 8: 69 \% \text { vs. } 43 \% \text {; } \\
P<0.001 \\
\text { Week } 12: 76 \% \text { vs. } 44 \% \text {; } \\
P<0.001\end{array}$ \\
\hline $\begin{array}{l}\text { Krause et al. [36] } \\
\text { R, DB, PBO-C, MC } \\
\text { Alosetron } 0.5 \mathrm{mg} \text { q.d., } \\
1 \mathrm{mg} \text { q.d., or } 1 \mathrm{mg} \\
\text { b.i.d. or PBO for } 12 \\
\text { weeks and } 4 \text {-week } \\
\text { follow-up }\end{array}$ & $\begin{array}{l}\text { Women with severe IBS- } \\
\text { D } \geq 6 \text { months (Rome II, } \\
n=705 \text {; alosetron: } 0.5 \mathrm{mg} \\
\text { q.d. } n=177,1 \mathrm{mg} \text { q.d. } \\
n=175,1 \mathrm{mg} \text { b.i.d. } \\
n=177 ; \text { PBO } n=176 \text { ) } \\
\text { Diarrhea ( } \geq 50 \% \text { of days) and } \\
\text { mean stool consistency } \geq 3 \\
\text { (scale range, } 1-5 \text { ), or mean } \\
\text { stool consistency } \geq 3.5 \\
\text { plus } \geq 1 \text { of the following: } \\
\text { frequent and severe } \\
\text { abdominal pain/discomfort } \\
\text { score } \geq 2 \text { (scale range, } 0-4 \text { ); } \\
\text { frequent bowel movement } \\
\text { urgency or incontinence } \\
\text { ( } \geq 50 \% \text { of days); and } \\
\text { restricted daily activities } \\
\text { ( } \geq 25 \% \text { of days) }\end{array}$ & $\begin{array}{l}\% \text { patients with response on } \\
\text { IBS Global Improvement } \\
\text { Scale at week } 12^{\mathrm{e}} \\
\text { Alosetron }(0.5 \mathrm{mg} \text { q.d., } 1 \mathrm{mg} \\
\text { q.d., and } 1 \mathrm{mg} \text { b.i.d.) vs. } \\
\text { PBO: } \\
51 \%, 48 \% \text {, and } 43 \% \text { vs. } 31 \% \text {; } \\
P \leq 0.02 \text { for all }\end{array}$ & $\begin{array}{l}\text { Adequate relief of IBS pain } \\
\text { and discomfort, urgency, } \\
\text { and changes in GI } \\
\text { symptoms, and normalized } \\
\text { bowel pattern } \\
\text { Adequate relief of pain and } \\
\text { discomfort: alosetron (all } \\
\text { doses) treatment differences } \\
\text { of } 9-16 \% \text { vs. PBO; } \\
P \leq 0.04 \\
\text { Stool frequency and } \\
\text { consistency: alosetron (all } \\
\text { doses) vs. PBO; } P \leq 0.006 \\
\text { and } P \leq 0.001, \text { respectively }\end{array}$ \\
\hline
\end{tabular}


Table 3 continued

\begin{tabular}{|c|c|c|c|}
\hline $\begin{array}{l}\text { Study, design, and } \\
\text { treatment }\end{array}$ & Patient population & Primary efficacy outcome & $\begin{array}{l}\text { Key secondary efficacy } \\
\text { outcome(s) }\end{array}$ \\
\hline $\begin{array}{l}\text { Lacy et al. }[34]^{\mathrm{f}} \\
\text { OL, MC } \\
\text { Alosetron } 0.5 \mathrm{mg} \text { b.i.d. } \\
\text { for } 4 \text { weeks; up to } \\
1 \mathrm{mg} \text { b.i.d. for } 8 \\
\text { additional weeks }\end{array}$ & $\begin{array}{l}\text { Women with severe IBS- } \\
\text { D } \geq 6 \text { months (Rome III, } \\
n=192 \text {; alosetron evaluable } \\
\text { patients } n=105 \text { ) } \\
\text { Frequent and severe abdominal } \\
\text { pain/discomfort (scale range, } \\
0-10 \text { ); bowel movement } \\
\text { urgency; fecal incontinence; } \\
\text { disability; and restricted daily } \\
\text { activities }\end{array}$ & $\begin{array}{l}\text { Composite primary } \\
\text { endpoint: } \geq 30 \% \text { decrease } \\
\text { in weekly abdominal pain } \\
\text { and } \geq 50 \% \text { decrease in days/ } \\
\text { week with BSFS type } 6 \text { or } 7 \\
\text { stool consistency) } \\
43 \% \text { patients met responder } \\
\text { criteria during the } 12 \text { weeks }\end{array}$ & $\begin{array}{l}\text { Overall treatment responder } \\
\text { (met composite endpoint } \\
\text { for } \geq 6 \text { of } 12 \text { weeks) } \\
45 \% \text { overall responders }\end{array}$ \\
\hline
\end{tabular}

b.i.d. twice daily, BSFS Bristol Stool Scale, $D B$ double-blind, IBS irritable bowel syndrome, IBS-D irritable bowel syndrome with diarrhea, $I B S-M$ irritable bowel syndrome with mixed features, $M C$ multicenter, $O L$ open label, $P B O$ placebo, $P B O$ $C$ placebo-controlled, q.d. once daily, $R$ randomized

a Determined by patient response of yes or no to the weekly question, "In the past 7 days have you had adequate relief of your irritable bowel syndrome pain and discomfort symptoms?"

b Determined by patient response regarding their IBS symptoms (pain severity, urgency, stool consistency, stool frequency, bloating, and sense of incomplete evacuation) during the treatment and follow-up phases

c Determined by patient response of yes or no to the daily question, "Have you had satisfactory control of your bowel urgency today?"

d IBS Global Improvement rating: "Compared to the way you usually felt during the 3 months before you entered the study, are your IBS symptoms over the past 4 weeks substantially worse, moderately worse, slightly worse, no change, slightly improved, moderately improved, or substantially improved?" A responder was defined as a patient who reported either moderate or substantial improvement

e IBS Global Improvement Scale: "Compared to the way you usually felt during the 3 months before you entered the study, are your IBS symptoms over the past 4 weeks substantially worse, moderately worse, slightly worse, no change, slightly improved, moderately improved, or substantially improved?" A responder was defined as a patient who reported either moderate or substantial improvement

f This study was designed to evaluate alosetron using Rome III criteria and the FDA composite endpoint for patients who met the inclusion criteria defined in the alosetron package insert

clinical studies are available, there is generally a lack of study rigor or standardization of endpoints. This is in direct contrast to the quality of clinical evidence for rifaximin, eluxadoline, and alosetron. The frequency of administration and safety profiles of the approved agents differ, with both eluxadoline and alosetron indicated for administration as daily therapy, and rifaximin for administration as a 2-week course of therapy with up to two repeat courses to manage symptom recurrence noted in US prescribing information [9]. Reported $\mathrm{NNH}$ values for these agents substantially favor rifaximin, owing to its safety profile, which, across three large phase 3 studies, generally was comparable to that of placebo. Eluxadoline overall is well tolerated but has label restrictions in postcholecystectomy patients and those who have other pancreatobiliary risk factors. Alosetron has been associated with greater risks of severe AEs compared with placebo, although the reported rates of ischemic colitis and constipation have declined precipitously, subsequent to implementation of the REMS program. Of the three FDA-approved therapies, alosetron still has the most restrictive indication and remains reserved for the treatment of women with severe IBS-D. 


\section{ACKNOWLEDGEMENTS}

Funding. Salix Pharmaceuticals provided funding for technical editorial and medical writing assistance for this review, in addition to the journal's fee for open access publication.

Medical Writing and Editorial Assistance. Technical editorial and medical writing assistance was provided, under direction of the authors, by Sophie Bolick, Ph.D., and Sujata Swaminathan, Ph.D., Synchrony Medical Communications, LLC, West Chester, PA. Funding for this support was provided by Salix Pharmaceuticals, Bridgewater, NJ.

Authorship. All named authors meet the International Committee of Medical Journal Editors (ICMJE) criteria for authorship for this article, take responsibility for the integrity of the work as a whole, and have given their approval for this version to be published.

Disclosures. Darren M. Brenner has served as a consultant, advisor, and speaker for Salix, Synergy Pharmaceuticals, Allergan, Ironwood Pharmaceuticals, Shire, The GI Health Foundation, Medscape, and Pri-Med. Gregory S. Sayuk has served as a consultant for Synergy, Allergan, and Ironwood Pharmaceuticals; and as a speaker for Salix, Synergy, Allergan, and Ironwood Pharmaceuticals.

Compliance with Ethics Guidelines. This article is a review and based on previously published studies. The review does not contain any new studies with human participants or animals.

Data Availability. Data sharing is not applicable to this article, as no datasets were generated or analyzed during the current review.

Open Access. This article is distributed under the terms of the Creative Commons Attribution-NonCommercial 4.0 International License (http://creativecommons.org/licenses/ by-nc/4.0/), which permits any noncommercial use, distribution, and reproduction in any medium, provided you give appropriate credit to the original author(s) and the source, provide a link to the Creative Commons license, and indicate if changes were made.

\section{REFERENCES}

1. Lacy BE, Mearin F, Chang L, et al. Bowel disorders. Gastroenterology. 2016;150(6):1393-407.

2. Simren M, Palsson OS, Whitehead WE. Update on Rome IV criteria for colorectal disorders: implications for clinical practice. Curr Gastroenterol Rep. 2017;19(4):15.

3. Sperber AD, Dumitrascu D, Fukudo S, et al. The global prevalence of IBS in adults remains elusive due to the heterogeneity of studies: a Rome Foundation working team literature review. Gut. 2017;66(6):1075-82.

4. Lovell RM, Ford AC. Global prevalence of and risk factors for irritable bowel syndrome: a meta-analysis. Clin Gastroenterol Hepatol. 2012;10(7):712-21.

5. Hungin APS, Chang L, Locke GR, Dennis EH, Barghout V. Irritable bowel syndrome in the United States: prevalence, symptom patterns and impact. Aliment Pharmacol Ther. 2005;21(11):1365-75.

6. Sayuk GS, Wolf R, Chang L. Comparison of symptoms, healthcare utilization, and treatment in diagnosed and undiagnosed individuals with diarrhea-predominant irritable bowel syndrome. Am J Gastroenterol. 2017;112(6):892-9.

7. Buono JL, Carson RT, Flores NM. Health-related quality of life, work productivity, and indirect costs among patients with irritable bowel syndrome with diarrhea. Health Qual Life Outcomes. 2017;15(1):35.

8. Ford AC, Moayyedi P, Chey WD, et al. American College of Gastroenterology monograph on management of irritable bowel syndrome. Am J Gastroenterol. 2018;113(Suppl 2):1-18.

9. Xifaxan ${ }^{\circledR}$ (rifaximin) tablets, for oral use [package insert]. Bridgewater: Salix Pharmaceuticals; 2018.

10. Viberzi (eluxadoline) tablets, for oral use, CIV [package insert]. Madison: Allergan USA, Inc.; 2018.

11. Lotronex $^{\circledR}$ (alosetron hydrochloride) tablets [package insert]. Roswell: Sebela Pharmaceuticals Inc.; 2016.

12. Zeber-Lubecka N, Kulecka M, Ambrozkiewicz F, et al. Limited prolonged effects of rifaximin 
treatment on irritable bowel syndrome-related differences in the fecal microbiome and metabolome. Gut Microbes. 2016;7(5):397-413.

13. Fodor AA, Pimentel M, Chey WD, et al. Rifaximin is associated with modest, transient decreases in multiple taxa in the gut microbiota of patients with diarrhoea-predominant irritable bowel syndrome. Gut Microbes. 2019;10(1):22-33.

14. $\mathrm{Xu} \mathrm{D,} \mathrm{Gao} \mathrm{J,} \mathrm{Gillilland} \mathrm{M} \mathrm{III,} \mathrm{et} \mathrm{al.} \mathrm{Rifaximin} \mathrm{alters}$ intestinal bacteria and prevents stress-induced gut inflammation and visceral hyperalgesia in rats. Gastroenterology. 2014;146(2):484-96.

15. Mencarelli A, Renga B, Palladino G, et al. Inhibition of NF-kB by a PXR-dependent pathway mediates counter-regulatory activities of rifaximin on innate immunity in intestinal epithelial cells. Eur J Pharmacol. 2011;668(1-2):317-24.

16. Jin Y, Ren X, Li G, et al. Beneficial effects of rifaximin in post-infectious irritable bowel syndrome mouse model beyond gut microbiota. J Gastroenterol Hepatol. 2018;33(2):443-52.

17. Wade PR, Palmer JM, McKenney S, et al. Modulation of gastrointestinal function by MuDelta, a mixed $\mu$ opioid receptor agonist $/ \mu$ opioid receptor antagonist. Br J Pharmacol. 2012;167(5):1111-25.

18. Fujita W, Gomes I, Dove LS, Prohaska D, McIntyre G, Devi LA. Molecular characterization of eluxadoline as a potential ligand targeting mu-delta opioid receptor heteromers. Biochem Pharmacol. 2014;92(3):448-56.

19. Crowell MD. Role of serotonin in the pathophysiology of the irritable bowel syndrome. Br J Pharmacol. 2004;141(8):1285-93.

20. Pimentel M, Lembo A, Chey WD, et al. Rifaximin therapy for patients with irritable bowel syndrome without constipation. $\mathrm{N}$ Engl $\mathrm{J}$ Med. 2011;364(1):22-32.

21. Lembo A, Pimentel M, Rao SS, et al. Repeat treatment with rifaximin is safe and effective in patients with diarrhea-predominant irritable bowel syndrome. Gastroenterology. 2016;151(6):1113-21.

22. Schoenfeld P, Pimentel M, Chang L, et al. Safety and tolerability of rifaximin for the treatment of irritable bowel syndrome without constipation: a pooled analysis of randomised, double-blind, placebo-controlled trials. Aliment Pharmacol Ther. 2014;39(10):1161-8.

23. Pimentel M, Cash BD, Lembo A, Wolf RA, Israel RJ, Schoenfeld P. Repeat rifaximin for irritable bowel syndrome: no clinically significant changes in stool microbial antibiotic sensitivity. Dig Dis Sci. 2017;62(9):2455-63.

24. Shah E, Kim S, Chong K, Lembo A, Pimentel M. Evaluation of harm in the pharmacotherapy of irritable bowel syndrome. Am J Med. 2012;125(4):381-93.

25. Lembo AJ, Lacy BE, Zuckerman MJ, et al. Eluxadoline for irritable bowel syndrome with diarrhea. N Engl J Med. 2016;374(3):242-53.

26. Chey WD, Dove LS, Andrae DA, Covington PS. Early response predicts a sustained response to eluxadoline in patients with irritable bowel syndrome with diarrhoea in two phase 3 studies. Aliment Pharmacol Ther. 2017;10:1319-28.

27. US Department of Health and Human Services, Food and Drug Administration, Center for Drug Evaluation and Research. Guidance for industry: irritable bowel syndrome-clinical evaluation of drugs for treatment. http://www.fda.gov/ downloads/Drugs/Guidances/UCM205269.pdf.

Accessed 1 Apr 2019.

28. Cash BD, Lacy BE, Schoenfeld PS, Dove LS, Covington PS. Safety of eluxadoline in patients with irritable bowel syndrome with diarrhea. Am J Gastroenterol. 2017;112(2):365-74.

29. Lacy BE, Chey WD, Cash BD, Lembo AJ, Dove LS, Covington PS. Eluxadoline efficacy in IBS-D patients who report prior loperamide use. Am J Gastroenterol. 2017;112(6):924-32.

30. Brenner DM, Sayuk GS, Gutman CR, et al. Efficacy and safety of eluxadoline in patients with irritable bowel syndrome with diarrhea who report inadequate symptom control with loperamide: RELIEF phase 4 study. Am J Gastroenterol. 2019;114(9):1502-11.

31. Gawron AJ, Bielefeldt K. Risk of pancreatitis following treatment of irritable bowel syndrome with eluxadoline. Clin Gastroenterol Hepatol. 2018;16(3):378-84.

32. Understanding the benefits and risks: the Lotronex REMS program prescriber education slide deck. https://lotronexrems.com/pdf/REMS_Prgm_Slide_ Deck_FINAL_03232016.pdf. Accessed 28 Oct 2019.

33. Camilleri M, Mayer EA, Drossman DA, et al. Improvement in pain and bowel function in female irritable bowel patients with alosetron, a $5-\mathrm{HT}_{3}$ receptor antagonist. Aliment Pharmacol Ther. 1999;13(9):1149-59.

34. Lacy BE, Nicandro JP, Chuang E, Earnest DL. Alosetron use in clinical practice: significant improvement in irritable bowel syndrome symptoms 
evaluated using the US Food and Drug Administration composite endpoint. Ther Adv Gastroenterol. 2018;11:1-11.

35. Lembo T, Wright RA, Bagby B, et al. Alosetron controls bowel urgency and provides global symptom improvement in women with diarrhea-predominant irritable bowel syndrome. Am J Gastroenterol. 2001;96(9):2662-70.

36. Krause R, Ameen V, Gordon SH, et al. A randomized, double-blind, placebo-controlled study to assess efficacy and safety of $0.5 \mathrm{mg}$ and $1 \mathrm{mg}$ alosetron in women with severe diarrhea-predominant IBS. Am J Gastroenterol. 2007;102(8):1709-19.
37. Camilleri M, Chey WY, Mayer EA, et al. A randomized controlled clinical trial of the serotonin type 3 receptor antagonist alosetron in women with diarrhea-predominant irritable bowel syndrome. Arch Intern Med. 2001;161(14):1733-40.

38. Camilleri M, Northcutt AR, Kong S, Dukes GE, McSorley D, Mangel AW. Efficacy and safety of alosetron in women with irritable bowel syndrome: a randomised, placebo-controlled trial. Lancet. 2000;355(9209):1035-40.

39. Tong K, Nicandro JP, Shringarpure R, Chuang E, Chang L. A 9-year evaluation of temporal trends in alosetron postmarketing safety under the risk management program. Ther Adv Gastroenterol. 2013;6(5):344-57. 